\title{
Metformin in Reproductive Biology
}

\author{
Melanie Faure ${ }^{1 \dagger}$, Michael J. Bertoldo ${ }^{2 \dagger}$, Rita Khoueiry ${ }^{3}$, Alice Bongrani ${ }^{1}$, François Brion ${ }^{4}$, \\ Cecilia Giulivi ${ }^{5,6}$, Joelle Dupont ${ }^{1}$ and Pascal Froment ${ }^{1 *}$
}

${ }^{1}$ Unité de Physiologie de la Reproduction et des Comportements, Centre Val de Loire, Institut National de la Recherche Agronomique, UMR85, Nouzilly, France, ${ }^{2}$ Discipline of Obstetrics and Gynaecology, School of Women's and Children's Health, University of New South Wales, Sydney, NSW, Australia, ${ }^{3}$ Department of Development and Regeneration, Stem Cell Institute, KU Leuven, Leuven, Belgium, ${ }^{4}$ INERIS, Direction des Risques Chroniques, Pole VIVA, Unite d'ecotoxicologie in vitro et in vivo, BP2, Verneuil-en-Halatte, France, ${ }^{5}$ Department of Molecular Biosciences, School of Veterinary Medicine, University of California, Davis, Davis, CA, United States, ${ }^{6}$ Medical Investigations of Neurodevelopmental Disorders Institute, University of California, Davis, Davis, CA, United States

OPEN ACCESS

Edited by:

Benoit Viollet,

Institut National de la Santé et de la

Recherche Médicale (INSERM),

France

Reviewed by:

Linus R. Shao,

University of Gothenburg, Sweden

Daniel Rappolee,

Wayne State University School of

Medicine, United States

*Correspondence:

Pascal Froment

pascal.froment@inra.fr

tThese authors have contributed equally to this work

Specialty section

This article was submitted to

Cellular Endocrinology,

a section of the journal

Frontiers in Endocrinology

Received: 04 May 2018

Accepted: 29 October 2018

Published: 22 November 2018

Citation:

Faure M, Bertoldo MJ, Khoueiry $R$

Bongrani A, Brion F, Giulivi $C$,

Dupont J and Froment P (2018)

Metformin in Reproductive Biology.

Front. Endocrinol. 9:675.

doi: 10.3389/fendo.2018.00675
Initially produced in Europe in 1958, metformin is still one of the most widely prescribed drugs to treat type II diabetes and other comorbidities associated with insulin resistance. Metformin has been shown to improve fertility outcomes in females with insulin resistance associated with polycystic ovary syndrome (PCOS) and in obese males with reduced fertility. Metformin treatment reinstates menstrual cyclicity, decreases the incidence of cesareans, and limits the number of premature births. Notably, metformin reduces steroid levels in conditions associated with hyperandrogenism (e.g., PCOS and precocious puberty) in females and improves fertility of adult men with metabolic syndrome through increased testosterone production. While the therapeutical use of metformin is considered to be safe, in the last 10 years some epidemiological studies have described phenotypic differences after prenatal exposure to metformin. The goals of this review are to briefly summarize the current knowledge on metformin focusing on its effects on the female and male reproductive organs, safety concerns, including the potential for modulating fetal imprinting via epigenetics.

Keywords: testis, ovary, metformin, oocytes, spermatogenesis

\section{INTRODUCTION}

\section{Brief History of Metformin}

The insulin-response sensitizer metformin ( $N, N$-dimethylbiguanide) has been an important drug for the treatment of diabetes since the 1950's, being one of the most widely prescribed anti-hyperglycemic compounds. Metformin belongs to the biguanide family of anti-diabetic compounds that are related to galegine, a guanidine derivative from the French lilac (Galga officinalis). In the beginning of the twentieth century, a chemical study of active molecules contained in Galga officinalis demonstrated anti-hyperglycemic properties in diabetic patients (1). Metformin synthesized in 1958, showed similarities with galegine and lowered blood glucose in initial tests on animals $(2,3)$. Metformin decreases the glycemia through a reduction in hepatic gluconeogenesis and intestinal glucose absorption, with a general improvement in tissue insulin sensitivity and peripheral glucose uptake (4). It is a stable, low molecular weight hydrophilic compound, which upon administration to patients, it reaches numerous tissues including muscle, liver, pancreas, adipose tissue, hypothalamus, pituitary, and the gonads. 


\section{Cellular Targets of Metformin}

The exact molecular mechanism of metformin's action remains unclear. In the first publications, metformin's actions at the cellular level have been attributed to inhibition of Complex I of the mitochondrial respiratory chain, albeit at relatively high concentrations $(\mathrm{mM})(5-10)$. This inhibition results in a decline in ATP production by mitochondria and an increase in the [adenosine monophosphate to ATP ratio ([AMP]/[ATP]) leading to the activation of the AMP-activated protein kinase (AMPK) complex (11). AMPK is a critical cellular energy sensor that maintains cellular energy homeostasis. Following its activation, AMPK initiates energy-producing catabolic pathways including facilitation of cellular glucose uptake and stimulation of glucose transporter expression, glycolysis, fatty acid beta-oxidation, oxidative phosphorylation and mitochondrial biogenesis. This compensatory mechanism aims at restoring sufficient energy to maintain cellular homeostasis (12-15) Figure 1. AMPK activity often counteracts the actions of the mammalian target of rapamycin (mTOR), a central cell-growth factor controlled by extracellular growth triggers and nutrients.

However, the metformin-dependent mitochondrial Complex I inhibition can not account for all of metformin's effects suggesting that metformin may act in an AMPK-independent manner (12-14, 16-20). For instance, it has been described that metformin inhibits the mitochondrial redox shuttle glycerophosphate dehydrogenase. The limited conversion of lactate and glycerol to glucose results in lower hepatic gluconeogenesis $(21,22)$ (Figure 2). Other studies identified H3K27me3 demethylase, KDM6A/UTX as a metformin target based on a structure- and ligand-based bioinformatic analysis (23). Some of the antidiabetic effects of metformin seem to be mediated in part to changes in gut microbiota, thereby promoting the growth of short chain fatty acidproducing bacteria $(24,25)$. Other studies reported the effect of metformin on the mitochndrial permeability transition pore (26) whereas others on the effects of this drug on cell death (27).

\section{ABSORPTION AND DISTRIBUTION OF METFORMIN}

Metformin is used at daily doses of $30-50 \mathrm{mg} / \mathrm{kg}$ body weight to treat type II diabetes, reaching serum levels of $10-40 \mu \mathrm{M}$ $(28,29)$. It is absorbed through the small intestine, with peak concentrations $1-2 \mathrm{~h}$ after oral administration. Its plasma halflife is about 1-6h. No metabolites of metformin have been identified, and is excreted as such in the urine within $12 \mathrm{~h}$ (29).

Species-specific differences show that mice are $\sim 10$ times less sensitive to metformin than humans $(20,29,30)$. In mice, after daily administrations at $50 \mathrm{mg} / \mathrm{kg}$ body weight, the serum concentrations of metformin are 1.5 and $30 \mu \mathrm{M}$ for $500 \mathrm{mg} / \mathrm{kg}(30,31)$. In human, $10-40 \mu \mathrm{M}$ in blood level is reached with $30-50 \mathrm{mg}$ metformin/ $\mathrm{kg}(28,29)$. As such, daily administrations of $250-300 \mathrm{mg} / \mathrm{kg}$ of metformin to diabetic mice are significantly higher than those used in humans in order to obtain similar therapeutic benefits (30). These speciesspecific metformin examples are relevant, not only when doses are compared across species but also when interpreting potential effects and targets.

Once in plasma/serum, metformin reaches the intracellular milieu via a limited passive diffusion, while other studies indicated that cationic transporters (Organic Cation Transporter 1: OCT1, OCT2, and MATE1) are able to transport metformin intracellularly (32). It has been claimed that genetic polymorphisms in the genes coding for these transporters may alter the tissue distribution and pharmacological effect of metformin (33).

\section{METFORMIN'S POTENTIAL IMPACT ON INFERTILITY}

The bioenergetic, metabolic processes indicated above are critical to sustain a physiological function of the male and female gonads, therefore, in the following sections, we summarize the current knowledge on metformin in regard to its effects on the reproductive processes of males and females in humans and across species. We also discuss the safety of metformin and its potential epigenetic consequences for fetal imprinting.

\section{Clinical and Molecular Impact of Metformin in the Female Reproductive System}

Since polycystic ovary syndrome (PCOS) is often associated with obesity, metabolic syndrome, gestational diabetes, and T2DM and cardiovascular risk factors, it is not surprising that PCOS patients with insulin resistance and hyperandrogenism are treated with metformin. PCOS is a major health issue affecting $\sim 5-20 \%$ of reproductive age women, representing the most common ovarian pathology in the world. Based on the criteria of the 2003 Rotterdam Consensus, PCOS is characterized by at least two of the following three criteria: (a) oligo- or anovulation, (b) clinical and/or biochemical signs of hyperandrogenism, (c) presence of 12 or more follicles in each ovary measuring 2-9 $\mathrm{mm}$ in diameter and/or increased ovarian volume $(>10 \mathrm{ml})$ and the exclusion of other etiologies $(34,35)$. The immediate and shortterm effects of metformin in women affected with PCOS are in general beneficial. Metformin's treatment improves ovarian cyclicity and reduces gestational diabetes with no impact on the incidence of cesareans or premature births (36-38). While in some countries, metformin is prescribed during pregnancy to women suffering PCOS and gestational diabetes (39-41), the US Food and Drug Administration (FDA) indicated that the safety of metformin during pregnancy is still unclear $(28,42)$.

However, metformin's efficacy on ovulation and birth rate alone or in combination with clomiphene citrate, compared to clomiphene citrate treatment alone, is still a matter of debate (43-46). For example, an analysis of nine randomized trials including 816 women with PCOS has shown that metformin increased clinical pregnancy rates and decreased the risk of ovarian hyperstimulation syndrome, although there was no clear beneficial evidence for increased rates of live births $(47,48)$ or increasing the risk for birth 


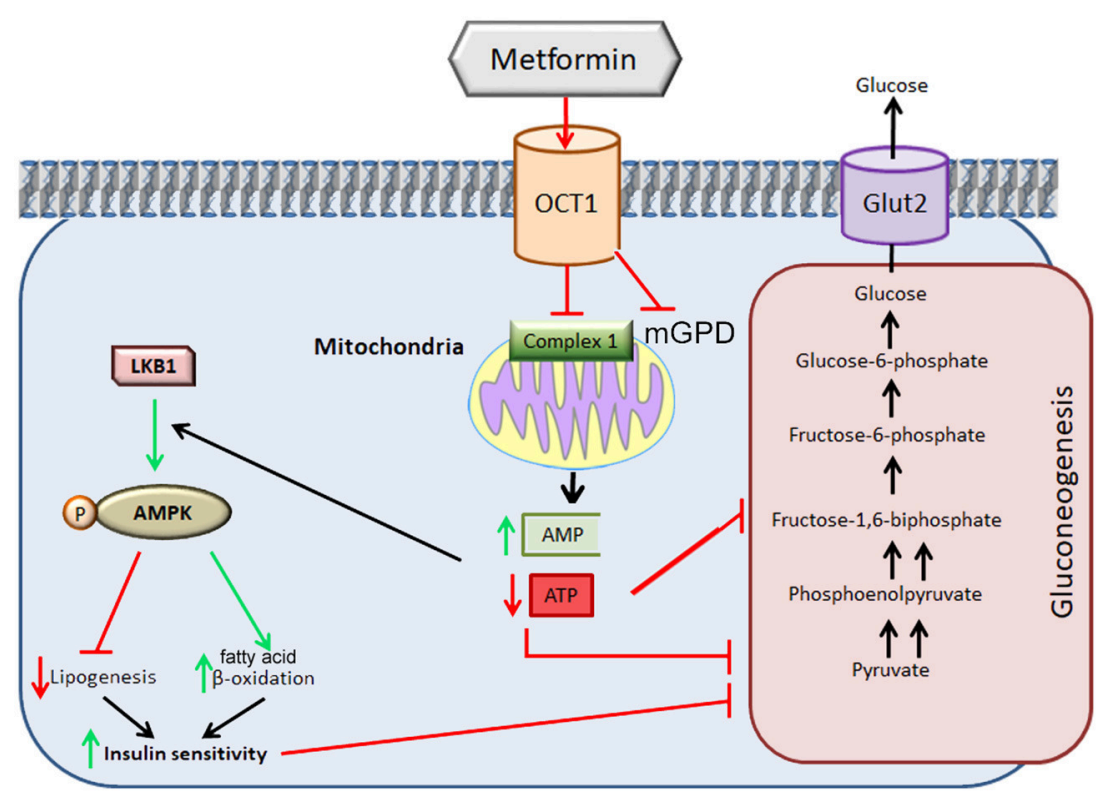

FIGURE 1 | Metformin-induced inhibition of mitochondrial Complex I. The direct inhibition of Complex I by metformin decreases the production of ATP ensuing in increases in AMP. The increase in the [AMP] to [ATP] ratio signals energy resulting in inhibition of high-energy demanding gluconeogenesis process. This ratio leads to the activation of the AMPK complex leading to a decrease in lipogenesis, increase in fatty acid beta-oxidation with an improvement in insulin sensitivity which allows the restoration of gluconeogenesis. The inhibition of metformin on mGDP prevents the use of lactate or glycerol for gluconeogenesis. OCT1: Organic Cation Ttransporter 1; LKB1: Liver Kinase B1; Glut2: GLUcose Transporter 2. mGPD: mitochondrial glycerophosphate dehydrogenase. Adapted from (20).

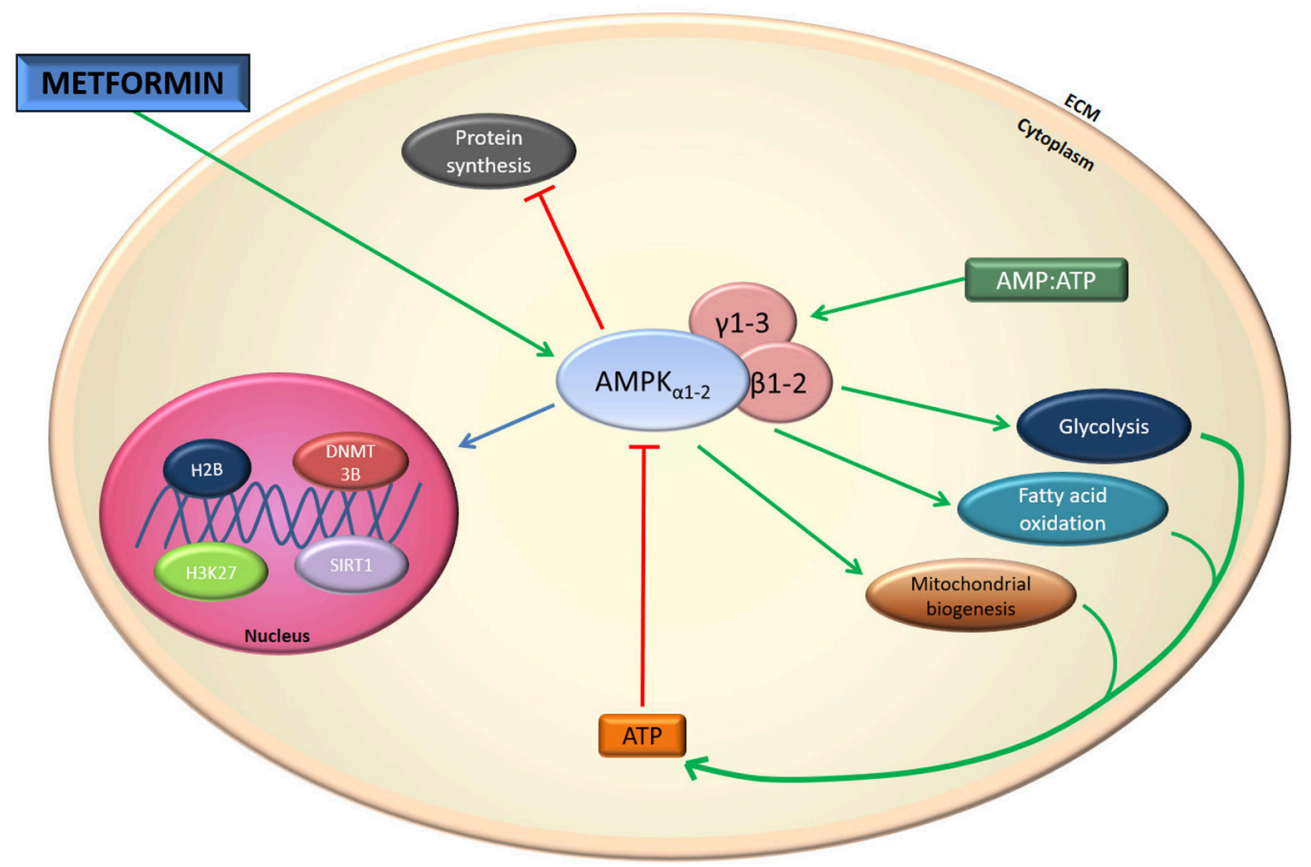

FIGURE 2 | Metformin effect on AMPK. Indirectly metformin activates AMPK. This activation results in mitochondrial biogenesis and glycolysis.

defects (49). The premature birth incidence was higher under metformin therapy (45). A recent meta-analysis described that ovulation rate was significantly higher under a combination of metformin and letrozole treatments than with other treatments (metformin alone, letrozole alone, metformin and clomiphene citrate, FSH, laparoscopic ovarian drilling) in 
females affected with PCOS resistant to clomiphene citrate treatment (50).

At the cellular level, metformin has been observed to regulate oocyte maturation. During bovine and porcine oocyte maturation, metformin is able to impede meiotic progression $(51,52)$. In the bovine oocyte, meiotic arrest was associated with an increase in AMPK activity, a reduction in MAPK ERK1/2 phosphorylation in both oocytes and cumulus cells, and the latency of ribosomal protein 6 and EEF2 (Eukaryotic elongation factor 2), two critical factors regulating protein synthesis in oocytes. Moreover, these effects were only evident in cumulusoocyte complexes and not in oocytes that had the cumulus compartment removed, indicating that at least in the bovine, cumulus cells are key for metformin to access the oocyte (52).

In a mouse model of PCOS, metformin treatment was explored to alleviate the negative influence of hyperandrogenism on oocyte quality (53). Metformin treatment of PCOS-affected dams was also able to partially reverse ovulatory dysfunction and improve oocyte quality and embryo development outcomes (53). These metformin-mediated improvements were associated with a reduction in oocyte lipid content and reactive oxygen species content, and improved mitochondrial function and glutathione levels (53), consistent with the effect of metformin on the oocytespecific AMPK knockout mouse model (50). While AMPK is expressed in all ovarian compartments across different species (cow, goat, ewe, sow, hen, rat) including women, deletion of the AMPK $\alpha 1$ subunit specifically in oocytes of mice results in a $27 \%$ reduction in litter size (54), highlighting the importance of the AMPK complex to oocyte developmental competence and fertility. Moreover, following in vitro fertilization of oocytespecific AMPK KO mice, a $68 \%$ reduction in the number of embryos passing the 2-cell stage was observed (54). This decrease in fertility could be partly explained to defective mitochondrial morphology and ATP synthesis (54). These results suggest that metformin could reverse the negative effects of hyperandrogenism on oocytes in PCOS individuals.

Mouse embryos exposed to metformin from the 2-cell to the blastocyst stage in vitro are smaller in size with lower cell numbers (55). The cell-to cell contact with trophectoderm was also altered because of an increase in tight junction permeability (55). In vivo, metformin reduced apoptosis in blastocysts of obese mice (56) possibly through an increase in NAMPT expression, but induced early bovine embryo arrest (57). Taken together, these studies demonstrate metformin's important contribution in the cross-talk between somatic cells and oocytes for the normal development of high-quality female germ cells and embryo developmental competence.

\section{Metformin and Male Reproductive Biology}

In males, metformin is prescribed for the treatment of T2DM. It is well-known that T2DM alters spermatogenesis in males, decreasing both sperm number and quality (58-60), resulting in reduced fertility. Furthermore, in utero exposure to metformin reduces fetal testicular size and the population of Sertoli cells (SC) (61). It is possible that these processes are driven by metformin-mediated increase in lactate production with a decrease in testosterone secretion (61). Metformin impacts the cell cycle by decreasing FSH-induced proliferation and increasing Cyclin-Dependent Kinase Inhibitor (CDKI) and inhibiting cyclin D in primary cultures of mouse Sertoli cells (62) (see Figure 3).

However, administration of metformin (for 4 or 8 weeks at doses of 100 or $500 \mathrm{mg} / \mathrm{kg}$ ) to adult, non-obese rats did not impact sperm number, sperm motility, or the percentage of abnormal spermatozoa (63) (see Table 1). In contrast, obesity induced an increase in the number of sperm abnormalities and a decrease in the spermatozoa concentration and motility which was rescued by metformin administration (63). In obese patients, metformin treatment improves sperm concentration and motility in the same way as observed in obese rats (63-66) as judged by the decreased number of morphological defects, with higher concentration and motility of sperm (64). In humans, it appears that a treatment for several months with metformin $(850 \mathrm{mg} / \mathrm{day}$ during the first week, $1,700 \mathrm{mg} /$ day during the second week, and $2,550 \mathrm{mg}$ /day until the end of 6 months of treatment) can increase the serum testosterone and LH pulsatility of obese individuals (64). This suggests that metformin can modulate and improve pituitary LH pulsatility and regulate Leydig cell steroidogenesis in testis. Recently, it has been shown that metformin decreases sperm motility in pigs (67), correlated with an increase in the viability of the spermatozoa after $24 \mathrm{~h}$ storage (see Table 1). In a model of testicular ischemia-stress-triggered apoptosis-metformin pre-treatment reduced both oxidative stress and the loss of germ cells, thereby limiting injury on sperm production, suggesting that metformin has cytoprotective effects (68).

Other studies have exposed rodents (rat, rabbit) to metformin in different metabolic models. Either diabetes or obesity induced by fatty acid-rich diet have shown that metformin could limit the decrease in testicular weight, and the thickness of the seminiferous epithelium $(66,69,70)$. Depending on the report, the testosterone concentrations and sperm concentrations were improved following the treatment $(63,65,66,71)$. In rabbit, the metformin treatment showed a negative effect on concentration, mobility and number of morphological abnormalities of spermatozoa (71).

In birds, metformin $(1 \mathrm{mM})$ treatment increased viability, mobility and acrosomal response of chicken sperm (72). During chicken seminiferous tubule culture, $48 \mathrm{~h}$ of metformin treatment $(5 \mathrm{mM})$ induced a decrease in the rate of proliferative germ cells number (73). This effect was opposite to that observed in equines. Metformin (up to $10 \mathrm{mM}$ ) did not induce any effects on viability and mobility of sperm or phosphorylation of AMPK in horses (74).

In regards to the mechanism leading to decreased male fertility, and considering that in mice both the AMPK $\alpha 1$ and $\alpha 2$ subunits are expressed in Leydig, Sertoli and male germ cells (75) with a predominant expression of $\alpha 1$ subunit over $\alpha 2$ (75 vs. $25 \%$ ) (76), it is possible that metformin impacts spermatogenesis and steroidogenesis in the testes partly through the AMPK pathway. It has been shown that AMPK activation by metformin in rat cultured Sertoli cells induces an increase in lactate production without changes in LDH (lactate dehydrogenase) activity. However, a decrease in the expression 


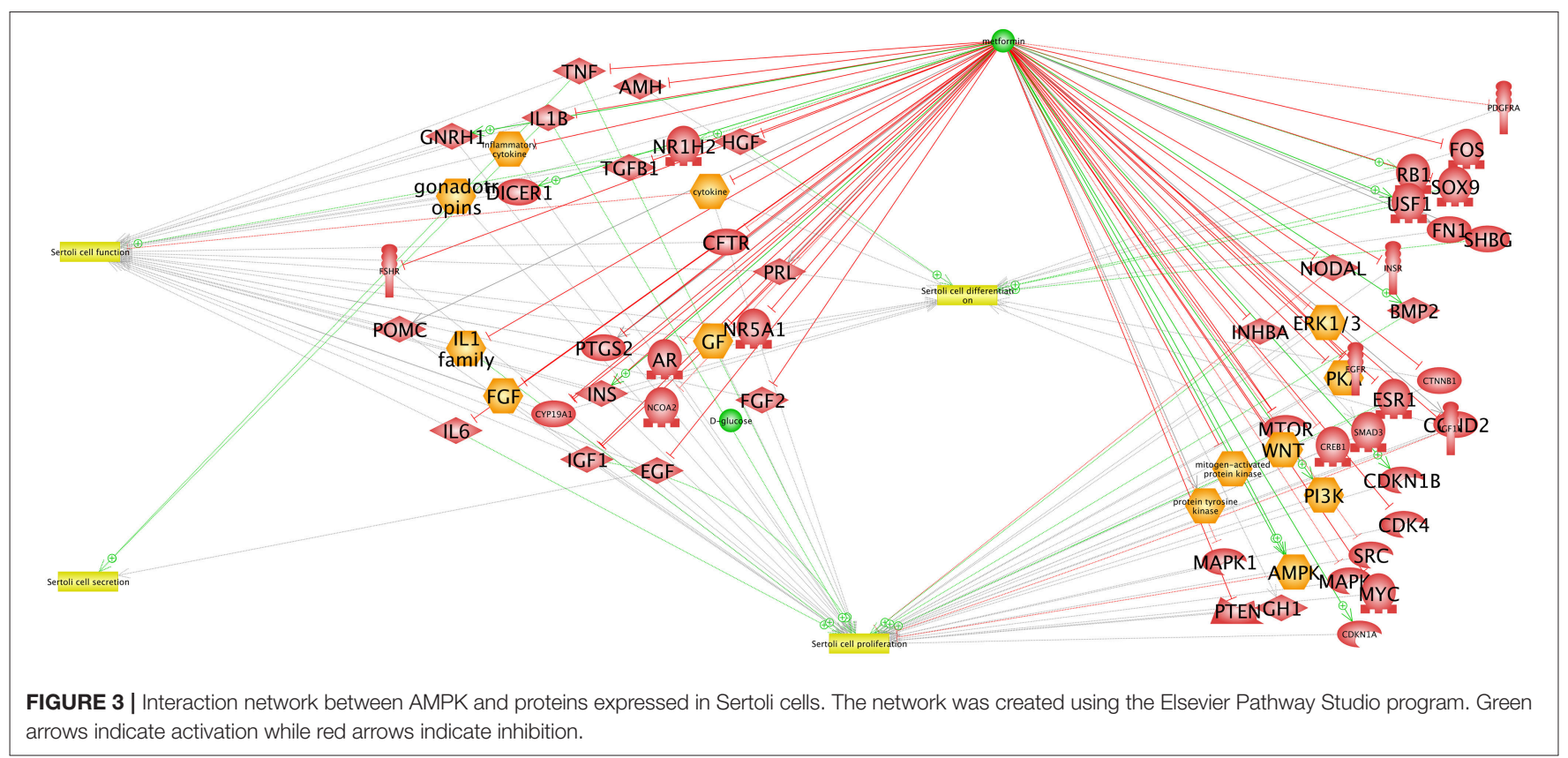

of MCT4 (monocarboxylate transporter 4), GLUT1, GLUT3 and an increase in the concentrations of alanine and acetate were also reported (77) suggesting activation of glycolysis without concomitant increase in mitochondrial bioenergetics.

Collectively, these studies suggested that obesity (or the metabolic changes associated with this condition) or a high fat diet may set the basis of an increased susceptibility to infertility issues. Metformin (in a dose, biological sample, and speciesspecific manner) treatment has the potential to activate targets resulting in an overall improvement of fertility.

\section{METFORMIN AND STEROIDOGENESIS}

In females, the impact of metformin on androgen synthesis is controversial (78-80). It is argued that metformin may reduce androgen levels indirectly through the resumption of ovulation. Several studies have shown that treatment with metformin induces a reduction in the hyperinsulinemia and hyperandrogenism that is associated with PCOS in obese and non-obese patients $(81,82)$. It has been suggested that metformin reduces hyperandrogenism through its ability to modulate both ovarian and adrenal androgen output, reducing LH secretion and increasing in some cases, sex hormone binding globulin. The ability of metformin to reduce the androgen levels seems to be variable according to the studies $(83,84)$.

Metformin has been shown to regulate steroidogenesis through a number of different mechanisms and cell types. Culture of luteinized granulosa cells exposed to the pre-ovulatory LH surge and with metformin lowers progesterone and estradiol syntheses in the same manner as non-luteinized granulosa cells exposed to either FSH or insulin (85). Rice et al. and Fuhrmeister et al. have demonstrated, that metformin induces a decrease in estradiol synthesis via the inhibition of aromatase expression by the MAPK signaling pathway $(86,87)$. However, metformin also induces activation of insulin-dependent AMPK pathways involved in lactate production by human granulosa cells $(88,89)$. Incubation of a human theca cell line with metformin induces a decline in androstenedione synthesis (90), possibly via the activation of AMPK.

In males, Tartarin et al. demonstrated that exposure of mice and human fetal testes to metformin decreases testosterone production. In vivo, administration of metformin resulted in a decrease in testosterone secretion, however, this effect was reversed when metformin administration was stopped (61). Conversely in humans, it appears that several months of treatment with metformin $(850 \mathrm{mg} /$ day during the first week, 1,700 mg/day during the second week, and 2,550 $\mathrm{mg} /$ day until the end of treatment period at 6 months) can increase the serum testosterone and LH levels of obese individuals.

In vitro studies have demonstrated that metformin significantly perturbs both androstenedione and testosterone syntheses in theca cells (90). Incubation of primary cultures of rat Leydig cells in the presence of an activator of AMPK, resveratrol, decreases hCG-induced testosterone synthesis by inhibition of P450c17 and StAR (91). Moreover, it have been demonstrated that metformin decreases the capacity of Leydig cells to secrete progesterone (92). In rats and cows, the incubation of granulosa cells with metformin also induces a decline in steroid synthesis that is correlated with an increase in AMPK phosphorylation. It appears that progesterone synthesis falls in the presence of metformin alone, but also during stimulation with FSH, IGF-1, or both $(93,94)$. This decrease can be explained by a decrease in the expression of some steroidogenic enzymes (3- $\beta$ HSD in the rat and $3-\beta$ HSD, CYP11A1, and StAR in the cow), an effect which is not observed in rats (95). 


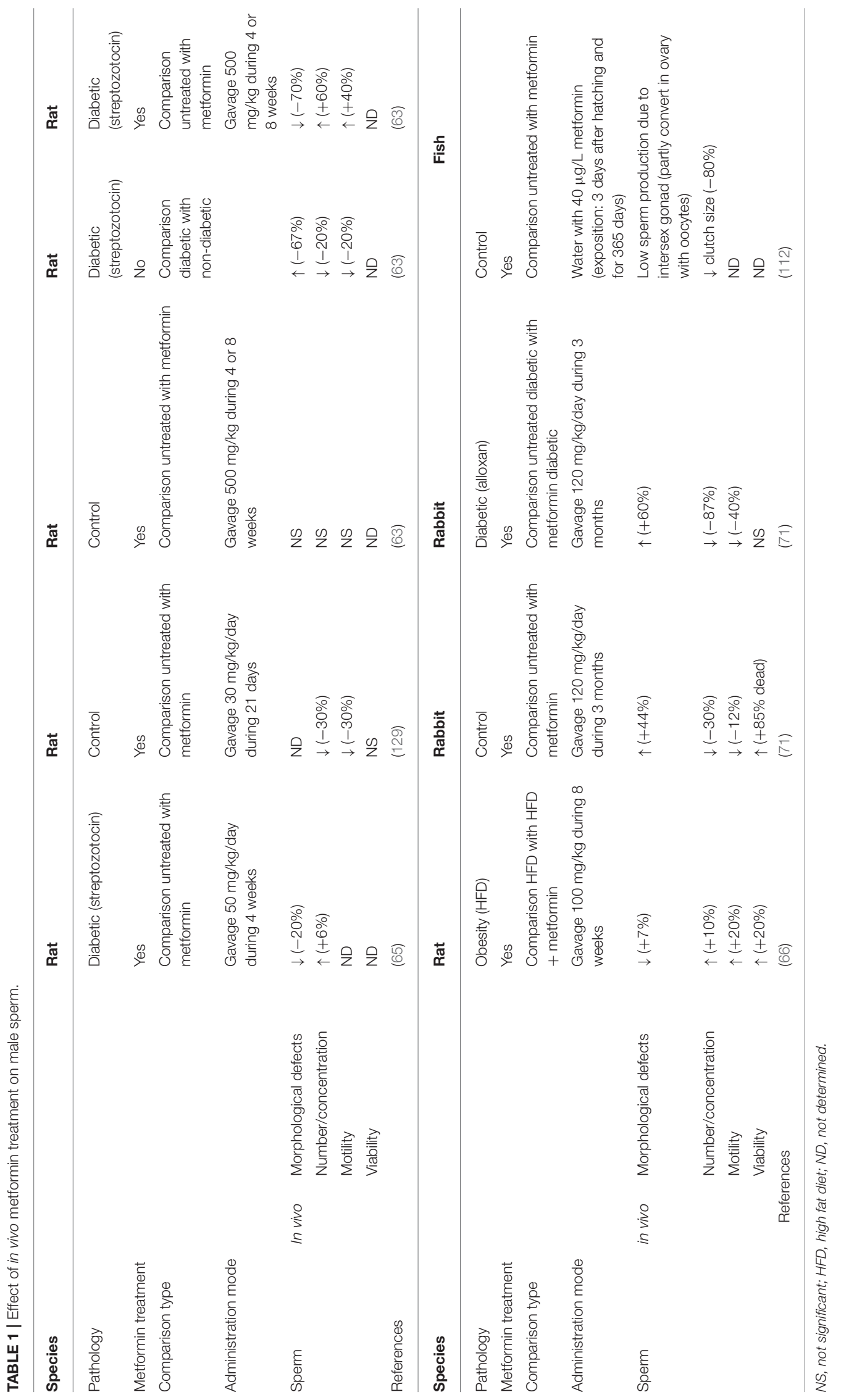


In human primary breast adipose tissue, consequences of metformin exposure revealed a significant decrease in the forskolin/phorbol ester induced aromatase expression (96).

Thus, based on the available literature, metformin acting via a number of mechanisms has the ability to modulate steroid levels both in vivo and in vitro.

\section{In utero EXPOSURE AND GONADAL DEVELOPMENT}

Metformin is the treatment of choice in cases of pregnancy disorders, such as gestational diabetes mellitus or preeclampsia (97). One hypothesis is that metformin regulates preeclampsia via mitochondrial function especially in the placenta and expression of antiangiogenic factors (97). However, the maternal administration of metformin reaches the fetus with umbilical cord concentrations (on average $457 \pm 335$ $\mu \mathrm{g} / \mathrm{L}$, equivalent to $3 \mu \mathrm{M})$ similar to those found in the maternal circulation $(730 \pm 440 \mu \mathrm{g} / \mathrm{L}$, equivalent to $5 \mu \mathrm{M})$ $(98,99)$. Salomaki et al. reported serum concentrations of only 0.174 and $0.130 \mu \mathrm{M}$ in the mother and fetus, respectively, at $24 \mathrm{~h}$ post-administration of daily doses of $300 \mathrm{mg} / \mathrm{kg}$ throughout pregnancy (100), suggesting that metformin may accumulate in certain tissues at higher concentrations than in plasma (101).

Considering that there are no reports of metformin inducing teratogenicity, the long-term health consequences of in utero metformin exposure remains elusive, primarily due to limited study designs $(102,103)$. In utero metformin-exposure resulted in children that were heavier, and with larger head size at $18 \mathrm{~m}$ of age (104). Recently, Hanem et al. demonstrated that in utero exposure to metformin resulted in children with a higher body mass index (BMI) and increased prevalence of overweight/obesity at 4 years of age compared to children of the placebo group (105), indicating that in humans, metformin administered during pregnancy has the ability to alter anthropometrics in the offspring.

But what is known on the effects of metformin on gonadal development during in utero exposure? Very limited studies exist, focusing mainly on the effects of metformin on male offspring. From these, no effect on testicular size was reported for young boys between 2.5 and 7 years of age born to mothers affected with gestational diabetes treated with either insulin or metformin and insulin (106). However, testicular size was not compared to boys born from placebo mothers and to individuals that had not yet reached the age of puberty. Tartarin et al. observed that embryonic exposure of mice to metformin during the first half of pregnancy had a negative impact on the testicular size of young mice and number of Sertoli cells (at $16.5 \mathrm{dpc}$ and $1 \mathrm{dpp}$ ) (61). At $16.5 \mathrm{dpc}$, a decrease in testicular testosterone concentration and Leydig cell count was also observed but was no longer found at birth. This suggests that while metformin is able to modulate mammalian testis development, some plasticity in the ability for the testis to recover exists during perinatal periods. Nonetheless, the long-term effects on fertility are yet to be determined.
In females with early symptoms of precocious puberty associated with hyperinsulinemia, metformin administration has been shown to delay the onset of clinical puberty and the pubertal increase in IGF1 levels $(107,108)$. Moreover, there was also a metformin-associated delay of menarche (108). The mode of action whereby metformin is able to delay pubertal onset and progression in girls remains to be understood. The observed delay of menarche appeared to be associated with falls in adiposity and insulin, leptin and IGF1 concentrations (107), suggesting that the effects of metformin on the ovary seemed to be indirect.

While exposure to metformin is usually through therapeutical administration, in the last decade, due to the increased use of metformin, accumulation of this drug has been reported in wastewater, drinking water and cosmetics, making it one of the 14 most active pharmacological molecules in the environment (109-111) with concentration reaching between 10 and $100 \mu \mathrm{g} / \mathrm{L}(1 \mu \mathrm{M})(112)$. Thus, it is possible that ingestion of metformin-containing water and/or use of metformincontaining cosmetics may elicit unwanted effects on humans as well as aquatic species exposed to metformin. Indeed, a 360-days long exposure of male fish (Pimephales promelas) to metformin $(40 \mu \mathrm{g} / \mathrm{l})$ leads to the appearance of an "intersex" gonads (113), with no intersex phenotype observed in mammals $(61,106)$. Gonadal estrogen and aromatase function play an important role in the gonad determinism in fish and avian species, thus, disruption of steroid production could lead to modification on gonadal development in these species. However, the exposure of cyp19a1b-GFP zebrafish model (GFP-driven promoter of aromatase in the central nervous system) to metformin $(0.3-30 \mu \mathrm{M})$ or its derivative guanylurea $(0.08-7 \mu \mathrm{M})$ did not result in changes in GFP expression suggesting a specific regulation of different aromatase transcripts by metformin depending on the promoter and tissue (gonad vs. central nervous system).

\section{METFORMIN AND EPIGENETICS}

In utero metformin exposure has been described safe for the fetus. Some evidence suggests that the beneficial effects of metformin are partly AMPK-dependent to counteract stress (114). However, it is important to follow the development of the offspring until adulthood to evaluate the risk to develop metabolic disorders through epigenetic information (114). Thus, if metformin is provided with a high-fat diet, then a significant increase in visceral fat depot of the offspring is observed during adulthood (99). In rodents, prenatal exposure to metformin modifies the hepatic fetal imprinting resulting in changes in the expression of several genes involved in the metabolism of cholesterol, lipids, fatty acids and steroids. Moreover, it decreases the expression of insulin-sensitive glucose transporter, GLUT4, in epididymal adipose tissue suggesting long-term effects, such as glucose intolerance in the testis (99). In a follow-up study of metformin in a gestational diabetes trial showed that prenatal exposure had a change in the pattern of fat distribution in children at 2 yearsold (same body fat mass but more subcutaneous fat (102). Taken 
together these studies point to a putative epigenetic effect of metformin which could be exerted during perinatal periods.

As possible mechanisms involved in epigenetics, indicated the section of Cellular Targets of Metformin, metformin directly targets the H3K27me3 demethylase KDM6A/UTX resulting in global augmentation of $\mathrm{H} 3 \mathrm{~K} 27 \mathrm{me} 3$ levels in cultured cells in vitro and in vivo (23). Moreover, several studies reported DNA hypermethylation following metformin treatment via its effect on one-carbon metabolism $(115,116)$. This increase in DNA methylation is probably due to an increase in the activity of $S$-adenosylhomocysteine hydrolase (SAHH). This enzyme hydrolyzes $S$-adenosylhomocysteine (SAH), a strong feedback inhibitor of $S$-adenosyl-L-methionine-dependent methyltransferases including DNA methyltransferases (DNMTs). Treating endometrial or ovarian cancer cells with metformin results in a decrease of the histone $\mathrm{H} 19$ levels and enables DNMT3B to increase DNA methylation (115). However, no statistically significant effect of metformin was observed in plasma homocysteine (metabolite that plays a critical role in DNA methylation) concentrations in PCOS patients with or without metformin treatment (117). A subgroup analyses suggested that metformin might induce Hcy accumulation when administered without folic acid or B-group vitamins supplementation (117). Further studies are warranted at demonstrating the links amongst metformin, B-group vitamins, and DNA methylation in patients with PCOS or infertility.

Alternatively, metformin could regulate epigenetic reprogramming through the activation of AMPK. A recent review reported the different mechanisms involved in the histone modifications in response to metformin-induced activation of AMPK phosphorylation of HATs (histone acetyltransferases), increased SIRT1 activity, and inhibition of class II HDACs (histone deacetylases) (118-120). AMPK has been shown to phosphorylate histone $\mathrm{H} 2 \mathrm{~B}$ by regulating $\mathrm{HDAC}$ in mouse embryonic fibroblasts (121). Metformin was shown to inhibit ovarian cancer via decreasing $\mathrm{H} 3 \mathrm{~K} 27$ trimethylation in an AMPK-dependent manner (122). Studies on Sertoli cells lacking AMPK $\alpha 1$ have highlighted the role of the $\alpha 1$ subunit of AMPK (123) metabolic activity and the secretion of many metabolites, such as glycine, malonate, succinate and alanine, which may act

\section{REFERENCES}

1. Simonet H, Tanret G. Sur les propriétés hypoglycemiantes du sulfate de galegine. In: Bull Soc Chim Biol. Paris (1927). p. 908-27.

2. Passik C. Glucophage: 40 ans au Service de la Diabétologie. Paris (1997).

3. Rinaldi D. La Metformine, une Vieille Molécule Pleine d'espoir. Doctoral Diss Fac Pharm, Univ de Lorraine (2012).

4. Natali A, Ferrannini E. Effects of metformin and thiazolidinediones on suppression of hepatic glucose production and stimulation of glucose uptake in type 2 diabetes: a systematic review. Diabetologia (2006) 49:434-41. doi: 10.1007/s00125-006-0141-7

5. El-Mir M-Y, Nogueira V, Fontaine E, Avéret N, Rigoulet $M$, Leverve $X$. Dimethylbiguanide inhibits cell respiration via an indirect effect targeted on the respiratory chain complex I. J Biol Chem. (2000) 275:223-8. doi: 10.1074/jbc.275. 1.223 on the enzymes modifying epigenetic marks. Oocytes lacking a1AMPK, a hyperacetylation of histone $\mathrm{H} 3$ and a decrease in the activity of SIRT1 is detected (123). Interestingly, the effects of metformin on HDACs are dissimilar because it increases the expression and/or activity of the class III HDAC SIRT1 (124-127) and pharmacological doses of metformin in the cryopreservation media of mouse sperm induced SIRT1 activity (128).

Taken together, while these studies show a link between metformin and DNA methylation status, many precise aspects of this link still need to be clarified.

\section{CONCLUSION}

After half a century, metformin has established itself as a first defense against insulin-dependent morbidities and undoubtedly has become a useful drug for improving fertility outcomes in both male and female patients. Metformin can modify testis and ovary function directly through AMPK-dependent and independent mechanisms. Its effects include improved sperm function and fertilization rates, oocyte quality and embryo development and reduction in miscarriage rates. The general consensus in the literature is that metformin is considered safe to use during pregnancy in regards to perinatal outcomes. However, adverse effects of metformin in the germ cell populations of offsprings exposed in utero and those on subsequent generations are less clear. While our understanding of the effects of metformin is continually progressing, further research is needed to have a more complete understanding of metformin's impact on fertility.

\section{AUTHOR CONTRIBUTIONS}

MF, MB, RK, AB, FB, CG, JD, and PF: redaction of different parts of the review.

\section{FUNDING}

This work received support from the Region Centre Val de Loire through the project OXYFERTI and by Institut National de la Recherche Agronomique. Alice Bongrani was supported by a French fellowship from the French Region Centre Val de Loire.
6. Owen MR, Doran E, Halestrap AP. Evidence that metformin exerts its anti-diabetic effects through inhibition of complex 1 of the mitochondrial respiratory chain. Biochem J. (2000) 614:607-14. doi: 10.1042/bj3480607

7. Detaille D, Guigas B, Leverve X, Wiernsperger N, Devos P. Obligatory role of membrane events in the regulatory effect of metformin on the respiratory chain function. Biochem Pharmacol. (2002) 63:1259-72. doi: 10.1016/S0006-2952(02)00858-4

8. Guigas B, Bertrand L, Taleux N, Foretz M, Wiernsperger N, Vertommen $\mathrm{D}$, et al. 5-Aminoimidazole-4-carboxamide-1-B-D-ribofuranoside and metformin inhibit hepatic glucose phosphorylation by an AMP-activated protein kinase-independent effect on glucokinase translocation. Diabetes (2006) 55:865-74. doi: 10.2337/diabetes.55.04.06.db05-1178

9. Cameron AR, Logie L, Patel K, Erhardt S, Bacon S, Middleton P, et al. Metformin selectively targets redox control of complex I energy transduction. Redox Biol. (2018) 14:187-97. doi: 10.1016/j.redox.2017. 08.018 
10. Wu C, Qiu S, Zhu X, Lin H, Li L. OCT1-mediated metformin uptake regulates pancreatic stellate cell activity. Cell Physiol Biochem. (2018) 47:1711-20. doi: 10.1159/000491003

11. Hardie DG, Ross FA, Hawley SA. AMPK: a nutrient and energy sensor that maintains energy homeostasis. Nat Rev Mol Cell Biol. (2012) 13:251-62. doi: $10.1038 / \mathrm{nrm} 3311$

12. Nascimben L, Ingwall JS, Lorell BH, Pinz I, Schultz V, Tornheim K, et al. Mechanisms for increased glycolysis in the hypertrophied rat heart. Hypertension (2004) 44:662-7. doi: 10.1161/01.HYP.0000144292.69599.0c

13. Jager S, Handschin C, St-Pierre J, Spiegelman BM. AMP-activated protein kinase (AMPK) action in skeletal muscle via direct phosphorylation of PGC-1a. Proc Natl Acad Sci USA. (2007) 104:12017-22. doi: 10.1073/pnas.0705070104

14. Coughlan KA, Valentine RJ, Ruderman NB, Saha AK. AMPK activation: a therapeutic target for type 2 diabetes? Diabetes Metab Syndr Obes. (2014) 7:241-53. doi: 10.2147/DMSO.S43731

15. Ke R, Xu Q, Li C, Luo L, Huang D. Mechanisms of AMPK in the maintenance of ATP balance during energy metabolism. Cell Biol Int. (2004) 28:229-36. doi: 10.1016/j.cellbi.2003.12.004

16. Gamble J, Lopaschuk GD. Insulin Inhibition of $5^{\prime}$ adenosine monophosphate-activated protein kinase in the heart results in activation of acetyl coenzyme A carboxylase and inhibition of fatty acid oxidation. Metabolism (1997) 46:1270-4.

17. Hardie DG. Sensing of energy and nutrients by AMP-activated protein kinase 1-4. Am J Clin Nutr. (2011) 93:891S-6. doi: 10.3945/ajcn.110.001925.1

18. Kukidome D, Nishikawa T, Sonoda K, Imoto K, Fujisawa K, Yano M, et al. Activation of AMP-activated protein kinase reduces hyperglycemiainduced mitochondrial reactive oxygen species production and promotes mitochondrial biogenesis in human umbilical vein endothelial cells. Diabetes (2006) 55:120-7. doi: 10.2337/diabetes.55.01.06.db05-0943

19. Karnewar S, Neeli PK, Panuganti D, Kotagiri S, Mallappa S, Jain N, et al. Metformin regulates mitochondrial biogenesis and senescence through AMPK mediated H3K79 methylation: relevance in age-associated vascular dysfunction. Biochim Biophys Acta (2018) 1864:1115-28. doi: 10.1016/j.bbadis.2018.01.018

20. Foretz M, Hébrard S, Leclerc J, Zarrinpashneh E, Soty M, Mithieux G, et al. Metformin inhibits hepatic gluconeogenesis in mice independently of the LKB1/AMPK pathway via a decrease in hepatic energy state. J Clin Invest. (2010) 120:2355-69. doi: 10.1172/JCI40671DS1

21. Madiraju AK, Erion DM, Rahimi Y, Zhang X-M, Braddock DT, Albright RA, et al. Metformin suppresses gluconeogenesis by inhibiting mitochondrial glycerophosphate dehydrogenase. Nature (2014) 510:542-6. doi: 10.1038/nature13270

22. Madiraju AK, Qiu Y, Perry RJ, Rahimi Y, Zhang X-M, Zhang D, et al. Metformin inhibits gluconeogenesis via a redox-dependent mechanism in vivo. Nat Med. (2018) 24:1384-94. doi: 10.1038/s41591-0180125-4

23. Cuyàs E, Verdura S, Llorach-Pares L, Fernández-Arroyo S, LucianoMateo F, Cabré N, et al. Metformin directly targets the H3K27me3 demethylase KDM6A/UTX. Aging Cell (2018) 17:e12772. doi: 10.1111/acel. 12772

24. Wu H, Esteve E, Tremaroli V, Khan MT, Caesar R, Mannerås-Holm L, et al. Metformin alters the gut microbiome of individuals with treatment-naive type 2 diabetes, contributing to the therapeutic effects of the drug. Nat Med. (2017) 23:850-8. doi: 10.1038/nm.4345

25. Bauer PV, Duca FA, Waise TMZ, Rasmussen BA, Abraham MA, Dranse HJ, et al. Metformin alters upper small intestinal microbiota that impact a glucose-SGLT1-sensing glucoregulatory pathway. Cell Metab. (2017) 27:10117. doi: 10.1016/j.cmet.2017.09.019

26. Lablanche S, Cottet-Rousselle C, Lamarche F, Benhamou PY, Halimi S, Leverve $\mathrm{X}$, et al. Protection of pancreatic INS-1 $\beta$-cells from glucoseand fructose-induced cell death by inhibiting mitochondrial permeability transition with cyclosporine A or metformin. Cell Death Dis. (2011) 2:e1346. doi: 10.1038/cddis.2011.15

27. El-Mir MY, Detaille D, R-Villanueva G, Delgado-Esteban M, Guigas B, Attia S, et al. Neuroprotective role of antidiabetic drug metformin against apoptotic cell death in primary cortical neurons. J Mol Neurosci. (2008) 34:77-87. doi: 10.1007/s12031-007-9002-1
28. Royal Australian College of General Practitioners. Gestational diabetes mellitus. In: General Practice Management of Type 2 Diabetes: 2016-18. (2014). Available online at: www.racgp.org.au

29. Graham GG, Punt J, Arora M, Day RO, Doogue MP, Duong JK, et al. Clinical pharmacokinetics of metformin. Clin Pharmacokinet. (2011) 50:8198. doi: 10.2165/11534750-000000000-00000

30. Hou M, Venier N, Sugar L, Musquera M, Pollak M, Kiss A, et al. Protective effect of metformin in CD1 mice placed on a high carbohydratehigh fat diet. Biochem Biophys Res Commun. (2010) 397:537-42. doi: $10.1016 /$ j.bbrc.2010.05.152

31. Gras V, Bouffandeau B, Montravers PH, Lalau JD. Effect of metformin on survival rate in experimental sepsis. Diabetes Metab. (2006) 32:147-50. doi: 10.1016/S1262-3636(07)70261-6

32. Gong L, Goswami S, Giacomini KM, Altman RB, Klein TE. Metformin pathways: pharmacokinetics and pharmacodynamics. Chemosphere (2012) 104:8897-901. doi: 10.1097/FPC.0b013e3283559b22

33. Shu Y, Brown C, Castro RA, Shi RJ, Lin ET, Owen RP, et al. Effect of genetic variation in the organic cation transporter 1, OCT1, on metformin pharmacokinetics. Clin Pharmacol Ther. (2008) 83:273-80. doi: 10.1038/sj.clpt.6100275

34. Fauser BCJM. Revised 2003 consensus on diagnostic criteria and long-term health risks related to polycystic ovary syndrome (PCOS). Hum Reprod. (2004) 19:41-7. doi: 10.1093/humrep/deh098

35. Cimino I, Casoni F, Liu X, Messina A, Parkash J, Jamin SP, et al. Novel role for anti-mullerian hormone in the regulation of $\mathrm{GnRH}$ neuron excitability and hormone secretion. Nat Commun. (2016) 7:1-12. doi: 10.1038/ncomms10055

36. Bertoldo MJ, Faure M, Dupont J, Froment P. Impact of metformin on reproductive tissues: an overview from gametogenesis to gestation. Ann Transl Med. (2014) 2:1-13. doi: 10.3978/j.issn.2305-5839.2014.06.04

37. Vanlalhruaii, Dasgupta R, Ramachandran R, Mathews JE, Regi A, Thomas $\mathrm{N}$, et al. How safe is metformin when initiated in early pregnancy? A retrospective 5-year study of pregnant women with gestational diabetes mellitus from India. Diabetes Res Clin Pract. (2018) 137:47-55. doi: 10.1016/j.diabres.2018.01.002

38. Brown J, Grzeskowiak L, Williamson K, Downie Michelle R, Crowther Caroline A. Insulin for the treatment of women with gestational diabetes. Cochrane Database Syst Rev. (2016). 11:1-294. doi: 10.1002/14651858.CD012037

39. New Zealand Ministry of Health. Screening, Diagnosis and Management of Gestational Diabetes in New Zealand: A Clinical Practice Guideline. (2014). Available online at: www.health.govt.nz

40. Network SIG. Management of Diabetes: A National Clinical Guideline (SIGN Publication o. 116.) (2008) SIGN. Available online at: www.sign.ac.uk/ guidelines/fulltext/

41. National Institute for Health and Care Excellence (NICE). Diabetes in Pregnancy: Management From Preconception to the Postnatal Period (2015). Available online at: https://www.nice.org.uk/guidance/ng3

42. Association AD. Management of diabetes in pregnancy. Diabetes Care (2017) 40:S114-9. doi: 10.2337/dc17-S016

43. Palomba S, Pasquali R, Orio F Jr., Nestler JE. Clomiphene citrate, metformin or both as first-step approach in treating anovulatory infertility in patients with polycystic ovary syndrome (PCOS): a systematic review of head-to-head randomized controlled studies and meta-analysis. Clin Endocrinol (Oxf). (2009) 70:311-21. doi: 10.1111/j.1365-2265.2008.03369.x

44. Tang $\mathrm{T}$, Lord J, Norman R, Yasmin E, Balen A. Insulin-sensitising drugs (metformin, rosiglitazone, pioglitazone, D-chiro-inositol) forwomenwith polycystic ovary syndrome, oligo amenorrhoea and subfertility. Cochrane Database Syst Rev. (2012) 5-7:CD003053. doi: 10.1002/14651858.CD003053.pub5

45. Petersen KB, Pedersen NG, Pedersen AT, Lauritsen MP, Freiesleben N la C. Mono-ovulation in women with polycystic ovary syndrome: a clinical review on ovulation induction. Reprod Biomed. (2016) 32:563-83. doi: 10.1016/j.rbmo.2016.03.006

46. Misso ML, Costello MF, Garrubba M, Wong J, Hart R, Rombauts L, et al. Metformin versus clomiphene citrate for infertility in non-obese women with polycystic ovary syndrome: a systematic review and meta-analysis. Hum Reprod. (2013) 19:2-11. doi: 10.1093/humupd/dms036 
47. Tso LO, Costello MF, Albuquerque LET, Andriolo RB, Macedo CR. Metformin treatment before and during IVF or ICSI in women with polycystic ovary syndrome. Cochrane Database Syst Rev. (2009) 2:CD006105. doi: 10.1002/14651858.CD006105.pub3

48. Tso LO, Costello MF, Albuquerque LET, Andriolo RB, Marjoribanks J, MacEdo CR. Metformin treatment before and during in vitro fertilization or intracytoplasmic sperm injection in women with polycystic ovary syndrome: summary of a cochrane review. Fertil Steril. (2015) 104:542-4. doi: 10.1016/j.fertnstert.2015.05.038

49. Cassina M, Dona M, Di Gianantonio E, Litta P, Clementi M. First-trimester exposure to metformin and risk of birth defects: a systematic review and meta-analysis. Hum Reprod. (2014) 20:656-69. doi: 10.1093/humupd/dmu022

50. Yu Y, Fang L, Zhang R, He J, Xiong Y, Guo X, et al. Comparative effectiveness of 9 ovulation-induction therapies in patients with clomiphene citrateresistant polycystic ovary syndrome: a network meta-analysis. Sci Rep. (2017) 7:1-12. doi: 10.1038/s41598-017-03803-9

51. Mayes MA, Laforest MF, Guillemette C, Gilchrist RB, Richard FJ. Adenosine 5 -monophosphate kinase-activated protein kinase (PRKA) activators delay meiotic resumption in porcine oocytes. Biol Reprod. (2007) 76:589-97. doi: 10.1095/biolreprod.106.057828

52. Tosca L, Uzbekova S, Chabrolle C, Dupont J. Possible role of 5 'AMPactivated protein kinase in the metformin-mediated arrest of bovine oocytes at the germinal vesicle stage during in vitro maturation. Biol Reprod. (2007) 77:452-65. doi: 10.1095/biolreprod.107.060848

53. Huang Y, Yu Y, Gao J, Li R, Zhang C. Impaired oocyte quality induced by dehydroepiandrosterone is partially rescued by metformin treatment. PLoS ONE (2015) 10:e0122370. doi: 10.1371/journal.pone.0122370

54. Bertoldo MJ, Guibert E, Faure M, Ramé C, Foretz M, Viollet B, et al. Specific deletion of AMP-activated protein kinase $(\alpha 1 \mathrm{AMPK})$ in murine oocytes alters junctional protein expression and mitochondrial physiology. PLoS ONE (2015) 10:e0119680. doi: 10.1371/journal.pone.0119680

55. Calder MD, Edwards NA, Betts DH, Watson AJ. Treatment with AICAR inhibits blastocyst development, trophectodermdifferentiation and tight junction formation and function in mice. Mol Hum Reprod. (2017) 23:77185. doi: 10.1093/MOLEHR/GAX050

56. Louden ED, Luzzo KM, Jimenez PT, Chi T, Chi M, Moley KH. TallyHO obese female mice experience poor reproductive outcomes and abnormal blastocyst metabolism which is reversed by metformin. Reprod Fertil Dev. (2014) 1:31-9. doi: 10.1071/RD14339

57. Pikiou O, Vasilaki A, Leondaritis G, Vamvakopoulos N, Messinis IE. Effects of metformin on fertilisation of bovine oocytes and early embryo development: possible involvement of AMPK3-mediated TSC2 activation. Zygote (2014) 23:58-67. doi: 10.1017/S0967199413000300

58. Sermondade N, Dupont C, Faure C, Boubaya M, Cédrin-Durnerin I, Chavatte-Palmer $\mathrm{P}$, et al. Body mass index is not associated with sperm-zona pellucida binding ability in subfertile males. Asian J Androl. (2013) 15:626-9. doi: 10.1038/aja.2013.10

59. Kort HI, Massey JOEB, Elsner CW, Mitchell-leef D, Shapiro DB, Witt MA, et al. Impact of body mass index values on sperm quantity and quality. $J$ Androl. (2006) 27:1150-2. doi: 10.2164/jandrol.05124

60. Dupont C, Faure C, Sermondade N, Boubaya M, Eustache F, Clément P, et al. Obesity leads to higher risk of sperm DNA damage in infertile patients. Asian J Androl. (2013) 15:622-5. doi: 10.1038/aja.2013.65

61. Tartarin P, Moison D, Guibert E, Dupont J, Habert R, Rouiller-Fabre V, et al. Metformin exposure affects human and mouse fetal testicular cells. Hum Reprod. (2012) 27:3304-14. doi: 10.1093/humrep/des264

62. Riera MF, Regueira M, Galardo MN, Pellizzari EH, Meroni SB, Cigorraga SB. Signal transduction pathways in FSH regulation of rat Sertoli cell proliferation. Am J Physiol Endocrinol Metab. (2012) 302:E914-23. doi: 10.1152/ajpendo.00477.2011

63. Attia SM, Helal GK, Alhaider AA. Assessment of genomic instability in normal and diabetic rats treated with metformin. Chem Biol Interact. (2009) 180:296-304. doi: 10.1016/j.cbi.2009.03.001

64. Morgante G, Tosti C, Orvieto R, Musacchio MC, Piomboni P, De Leo V. Metformin improves semen characteristics of oligo-teratoasthenozoospermic men with metabolic syndrome. Fertil Steril. (2011) 95:2150-2. doi: 10.1016/j.fertnstert.2010.12.009
65. Rabbani SI, Devi K, Khanam S. Role of pioglitazone with metformin or glimepiride on oxidative stress-induced nuclear damage and reproductive toxicity in diabetic rats. J Med Sci. (2010) 17:3-11.

66. Yan W, Mu Y, Yu N, Yi T, Zhang Y, Pang X, et al. Protective effects of metformin on reproductive function in obese male rats induced by high-fat diet. J Assist Reprod Genet. (2015) 32:1097-104. doi: 10.1007/s10815-015-0506-2

67. Hurtado de Llera A, Martin-Hidalgo D, Gil MC, Garcia-Marin LJ, Bragado MJ. AMP-activated kinase AMPK is expressed in boar spermatozoa and regulates motility. PLoS ONE (2012) 7:e38840. doi: 10.1371/journal.pone.0038840

68. Ghasemnejad-Berenji M, Ghazi-Khansari M, Yazdani I, Nobakht M, Abdollahi A, Ghasemnejad-Berenji $\mathrm{H}$, et al. Effect of metformin on germ cell-specific apoptosis, oxidative stress and epididymal sperm quality after testicular torsion/detorsion in rats. Andrologia (2017) 50:1-8. doi: 10.1111/and.12846

69. Nasrolahi O, Khaneshi F, Rahmani F, Razi M. Honey and metformin ameliorated diabetes-induced damages in testes of rat; correlation with hormonal changes. Iran J Reprod Med. (2013) 11:1013-20.

70. Ayuob NN, Hussam ASM, Soad SA. Impaired expression of sex hormone receptors in male reproductive organs of diabetic rat in response to oral antidiabetic drugs. Folia Histochem Cytobiol. (2015) 53:35-48. doi: 10.5603/FHC.a2015.0005

71. Naglaa ZHE, Hesham AM, Fadil HA, Motal ASM. Impact of metformin on immunity and male fertility in rabbits with alloxan-induced diabetes. $J \mathrm{Am}$ Sci. (2010) 6:417-26.

72. Nguyen TMD, Alves S, Grasseau I, Métayer-Coustard S, Praud C, Froment $\mathrm{P}$, et al. Central role of $5^{\prime}$-AMP-activated protein kinase in chicken sperm functions. Biol Reprod. (2014) 91:1-15. doi: 10.1095/biolreprod.114. 121855

73. Faure M, Guibert E, Alves S, Pain B, Ramé C, Dupont J, et al. The insulin sensitiser metformin regulates chicken Sertoli and germ cell populations. Reproduction (2016) 151:527-38. doi: 10.1530/REP-15-0565

74. Córdova A, Strobel P, Vallejo A, Valenzuela P, Ulloa O, Burgos RA, et al. Cryobiology use of hypometabolic TRIS extenders and high cooling rate refrigeration for cryopreservation of stallion sperm: presence and sensitivity of 50 AMP-activated protein kinase (AMPK). Cry (2014) 69:473-81. doi: 10.1016/j.cryobiol.2014.10.008

75. Tartarin P, Guibert E, Touré A, Ouiste C, Leclerc J, Sanz N, et al. Inactivation of $\mathrm{AMPK} \alpha 1$ induces asthenozoospermia and alters spermatozoa morphology. Endocrinology (2012) 153:3468-81. doi: 10.1210/en. 2011-1911

76. Cheung PCF, Salt IP, Davies SP, Hardie DG, Carling D. Characterization of AMP-activated protein kinase $\gamma$-subunit isoforms and their role in AMP binding. Biochem (2000) 669:659-69. doi: 10.1042/bj34 60659

77. Alves MG, Martins AD, Vaz CV, Correia S, Moreira PI, Oliveira PF, et al. Metformin and male reproduction: effects on Sertoli cell metabolism. $\mathrm{Br} \mathrm{J}$ Pharmacol. (2014) 171:1033-42. doi: 10.1111/bph.12522

78. Arlt W, Auchus RJ, Miller WL. Thiazolidinediones but not metformin directly inhibit the steroidogenic enzymes P450c17 and 3ß-hydroxysteroid dehydrogenase. J Biol Chem. (2001) 276:16767-71. doi: 10.1074/jbc.M100040200

79. Bailey C, Puah JA. Effect of metformin on glucose metabolism in mouse soleus muscle. Diabete Metab. (1986) 12:212-8.

80. Lashen H. Review: role of metformin in the management of polycystic ovary syndrome. Ther Adv Endocrinol Metab. (2010) 1:117-28. doi: $10.1177 / 2042018810380215$

81. Velazquez EM, Sosa F, Glueck CJ. Metformin therapy in polycystic ovary syndrome reduces hyperinsulinemia, insulin resistance, hyperandrogenemia, and systolic blood pressure, while facilitating normal menses and pregnancy. Metabolism (1994) 43:647-54. doi: 10.1016/0026-0495(94)90209-7

82. Nestler JE, Jakubowicz DJ. Lean women with polycystic ovary syndrome respond P450c17a activity and serum androgens. J Clin Endocrinol Metab. (1997) 82:4075-9.

83. Bailey C, Turner R. Metformin. N Engl J Med. (1998) 334:574-9. doi: 10.1056/NEJM199602293340906 
84. Harborne L, Fleming R, Lyall H, Sattar N, Norman J. Metformin or antiandrogen in the treatment of hirsutism in polycystic ovary syndrome. J Clin Endocrinol Metab. (2003) 88:4116-23. doi: 10.1210/jc.2003-030424

85. Mansfield R, Galea R, Brincat M, Hole D, Mason H. Metformin has direct effects on human ovarian steroidogenesis. Fertil Steril. (2003) 79:956-62. doi: 10.1016/S0015-0282(02)04925-7

86. Rice S, Pellatt L, Ramanathan K, Whitehead SA, Mason HD. Metformin inhibits aromatase via an extracellular signal-regulated kinase-mediated pathway. Endocrinology (2009) 150:4794-801. doi: 10.1210/en.2009-0540

87. Fuhrmeister I, Branchini G, Pimentel A, Ferreira G, Capp E, Brum I, et al. Human granulosa cells: insulin and insulin-like growth factor-1 receptors and aromatase expression modulation by metformin. Gynecol Obs Invest. (2014) 77:156-62. doi: 10.1159/000358829

88. Richardson MC, Ingamells S, Simonis CD, Cameron IT, Sreekumar R, Vijendren A, et al. Stimulation of lactate production in human granulosa cells by metformin and potential involvement of adenosine 5 monophosphateactivated protein kinase. J Clin Endocrinol Metab. (2009) 94:670-7. doi: 10.1210/jc.2008-2025

89. Pellatt LJ, Rice S, Mason HD. Phosphorylation and activation of AMPactivated protein kinase (AMPK) by metformin in the human ovary requires insulin. Reprod Dev. (2011) 152:1112-8. doi: 10.1210/en.2009-1429

90. Attia GR, Rainey WE, Carr BR. Metformin directly inhibits androgen production in human thecal cells. Fertil Steril. (2001) 76:517-24. doi: 10.1016/S0015-0282(01)01975-6

91. Svechnikov K, Spatafora C, Svechnikova I, Tringali C, Söder O. Effects of resveratrol analogs on steroidogenesis and mitochondrial function in rat Leydig cells in vitro. J Appl Toxicol. (2009) 29:673-80. doi: 10.1002/jat.1456

92. Rone MB, Midzak AS, Martinez-arguelles DB, Fan J, Ye X, Papadopoulos V. Steroidogenesis in MA-10 mouse leydig cells is altered via fatty acid import into the mitochondria. Biol Res Nurs. (2014) 91:1-14. doi: 10.1095/biolreprod.114.121434

93. Tosca L, Froment P, Solnais P, Ferre P, Foufelle F. Adenosine 5monophosphate-activated protein kinase regulates progesterone secretion in rat granulosa cells. Endocrinology (2005) 146:4500-13. doi: 10.1210/en.2005-0301

94. Tosca L, Chabrolle C, Uzbekova S, Dupont J. Effects of metformin on bovine granulosa cells steroidogenesis: possible involvement of adenosine 5 ' monophosphate-activated protein kinase (AMPK). Biol Reprod. (2007) 76:368-78. doi: 10.1095/biolreprod.106.055749

95. Mesbah F, Moslem M, Vojdani Z, Mirkhani H. Does metformin improve in vitro maturation and ultrastructure of oocytes retrieved from estradiol valerate polycystic ovary syndrome-induced rats. J Ovarian Res. (2015) 8:1-10. doi: 10.1186/s13048-015-0203-x

96. Samarajeewa NU, Ham S, Yang F, Simpson ER, Brown KA. Promoter-specific effects of metformin on aromatase transcript expression. Steroids (2011) 76:768-71. doi: 10.1016/j.steroids.2011.02.041

97. Romero R, Erez O, Hüttemann M, Maymon E, Panaitescu B, CondeAgudelo A, et al. Metformin, the aspirin of the 21st century: its role in gestational diabetes mellitus, prevention of preeclampsia and cancer, and the promotion of longevity. Am J Obstet Gynecol. (2017) 217:282-302. doi: 10.1016/j.ajog.2017.06.003

98. Tertti K, Laine K, Ekblad U, Rinne V, Ronnemaa T. The degree of fetal metformin exposure does not influence fetal outcome in gestational diabetes mellitus. Acta Diabetol. (2014) 51:731-8. doi: 10.1007/s00592-014-0570-6

99. Vanky E, Zahlsen K, Spigset O, Carlsen SM. Placental passage of metformin in women with polycystic ovary syndrome. Fertil Steril. (2005) 83:1575-8. doi: 10.1016/j.fertnstert.2004.11.051

100. Salomäki H, Vähätalo LH, Laurila K, Jäppinen NT, Penttinen A-M, Ailanen $\mathrm{L}$, et al. Prenatal metformin exposure in mice programs the metabolic phenotype of the offspring during a high fat diet at adulthood. PLoS ONE (2013) 8:e56594. doi: 10.1371/journal.pone.0056594

101. Wilcock C, Bailey CJ. Accumulation of metformin by tissues of the normal and diabetic mouse. Xenobiotica (1994) 24:49-57. doi: 10.3109/00498259409043220

102. Rowan JA, Rush EC, Obolonkin V, Battin M, Wouldes T, Hague WM. Metformin in gestational diabetes: the offspring follow-up (MiG TOFU): body composition at 2 years of age. Diabetes Care (2011) 34:2279-84. doi: $10.2337 / \mathrm{dc} 11-0660$
103. Ijäs H, Vääräsmäki M, Saarela T, Keravuo R, Raudaskoski T. A follow-up of a randomised study of metformin and insulin in gestational diabetes mellitus: growth and development of the children at the age of 18 months. BJOG (2015) 122:994-1000. doi: 10.1111/1471-0528.12964

104. Hjorth-Hansen A, Salvesen $\varnothing$, Hanem LGE, Eggebø T, Salvesen KA, Vanky E, et al. Fetal growth and birth anthropometrics in metformin-exposed offspring born to mothers with PCOS. J Clin Endocrinol Metab. (2018) 103:740-7. doi: 10.1210/jc.2017-01191

105. Hanem LGE, Stridsklev S, Júlíusson PB, Salvesen $\varnothing$, Roelants M, Carlsen $\mathrm{SM}$, et al. Metformin use in PCOS pregnancies increases the risk of offspring overweight at 4 years of age; follow-up of two RCTs. J Clin Endocrinol Metab. (2018) 103:1612-21. doi: 10.1210/jc.2017-02419

106. Tertti K, Toppari J, Virtanen HE, Sadov S, Rönnemaa T. Metformin treatment does not affect testicular size in offspring born to mothers with gestational diabetes. Rev Diabet Stud. (2016) 13:59-65. doi: 10.1900/RDS.2016.13.59

107. Ibáñez L, López-Bermejo A, Díaz M, Marcos MV, de Zegher F. Early metformin therapy (age 8-12 years) in girls with precocious pubarche to reduce hirsutism, androgen excess, and oligomenorrhea in adolescence. $J$ Clin Endocrinol Metab. (2011) 96:E1262-7. doi: 10.1210/jc.2011-0555

108. Ibáñez L, Ong K, Valls C, Marcos MV, Dunger DB, de Zegher F. Metformin treatment to prevent early puberty in girls with precocious pubarche. J Clin Endocrinol Metab. (2006) 91:2888-91. doi: 10.1210/jc.2006-0336

109. Trautwein C, Kümmerer K. Incomplete aerobic degradation of the antidiabetic drug Metformin and identification of the bacterial deadend transformation product Guanylurea. Chemosphere (2011) 85:765-73. doi: 10.1016/j.chemosphere.2011.06.057

110. Khan U, Nicell J. Human health relevance of pharmaceutically active compounds in drinking water. AAPS J. (2015) 17:558-85. doi: 10.1208/s12248-015-9729-5

111. Blair BD, Crago JP, Hedman CJ, Klaper RD. Pharmaceuticals and personal care products found in the Great Lakes above concentrations of environmental concern. Chemosphere (2013) 93:2116-23. doi: 10.1016/j.chemosphere.2013.07.057

112. Ter Laak T, Baken K. The occurrence, fate and ecological and human health risks of metformin and guanylurea in the water cycle-a literature review. KWR (2014) 1-24.

113. Niemuth NJ, Klaper RD. Emerging wastewater contaminant metformin causes intersex and reduced fecundity in fish. Chemosphere (2015) 135:3845. doi: 10.1016/j.chemosphere.2015.03.060

114. Puscheck EE, Bolnick A, Awonuga A, Yang Y, Abdulhasan M, Li Q, et al. Why AMPK agonists not known to be stressors may surprisingly contribute to miscarriage or hinder IVF/ART. J Assist Reprod Genet. (2018) 35:1359-66. doi: 10.1007/s10815-018-1213-6

115. Zhong T, Men Y, Lu L, Geng T, Zhou J, Mitsuhashi A, et al. Metformin alters DNA methylation genome-wide via the H19/SAHH axis. Oncogene (2017) 36:2345-54. doi: 10.1038/onc.2016.391

116. Cuyàs E, Fernández-Arroyo S, Verdura S, García RÁF, Stursa J, Werner $\mathrm{L}$, et al. Metformin regulates global DNA methylation via mitochondrial one-carbon metabolism. Oncogene (2018) 37:963-70. doi: 10.1038/onc. 2017.367

117. Zhang Q, Li S, Li L, Li Q, Ren K, Sun X, et al. Metformin treatment and homocysteine: a systematic review and meta-analysis of randomized controlled trials. Nutrients (2016) 8:E798: doi: 10.3390/nu8120798

118. Bridgeman SC, Ellison GC, Melton PE, Newsholme P, Mamotte CDS. Epigenetic effects of metformin: from molecular mechanisms to clinical implications. Diabetes Obes Metab. (2018) 20:1553-62. doi: 10.1111/dom. 13262

119. Banerjee P, Surendran H, Chowdhury DR, Prabhakar K, Pal R. Metformin mediated reversal of epithelial to mesenchymal transition is triggered by epigenetic changes in E-cadherin promoter. J Mol Med. (2016) 94:1397-409. doi: 10.1007/s00109-016-1455-7

120. Khan S, Jena G. Sodium butyrate reduces insulin-resistance, fat accumulation and dyslipidemia in type-2 diabetic rat: a comparative study with metformin. Chem Biol Interact. (2016) 254:124-34. doi: 10.1016/j.cbi.2016.06.007

121. Bungard D, Fuerth BJ, Zeng P-Y, Faubert B, Maas NL, Viollet B, et al. Signaling kinase AMPK activates stress-promoted transcription 
via histone H2B phosphorylation. Science (2010) 329:1201-5. doi: $10.1126 /$ science.1191241

122. Tang G, Guo J, Zhu Y, Huang Z, Liu T, Cai J, et al. Metformin inhibits ovarian cancer via decreasing H3K27 trimethylation. Int J Oncol. (2018) 52:1899-911. doi: 10.3892/ijo.2018.4343

123. Bertoldo MJ, Guibert E, Faure M, Guillou F, Ramé C, Nadal-Desbarats $\mathrm{L}$, et al. Specific deletion of AMP-activated protein kinase ( $\alpha 1 \mathrm{AMPK})$ in mouse Sertoli cells modifies germ cell quality. Mol Cell Endocrinol. (2016) 423:96-112. doi: 10.1016/j.mce.2016.01.001

124. Vigili de Kreutzenberg S, Ceolotto G, Cattelan A, Pagnin E, Mazzucato $\mathrm{M}$, Garagnani $\mathrm{P}$, et al. Metformin improves putative longevity effectors in peripheral mononuclear cells from subjects with prediabetes. A randomized controlled trial. Nutr Metab Cardiovasc Dis. (2015) 25:686-93. doi: 10.1016/j.numecd.2015.03.007

125. Caton PW, Nayuni NK, Kieswich J, Khan NQ, Yaqoob MM, Corder R. Metformin suppresses hepatic gluconeogenesis through induction of SIRT1 and GCN5. J Endocrinol. (2010) 205:97-106. doi: 10.1677/JOE-09-0345

126. Zhang E, Guo Q, Gao H, Xu R, Teng S, Wu Y. Metformin and resveratrol inhibited high glucose-induced metabolic memory of endothelial senescence through SIRT1/p300/p53/p21 pathway. PLoS ONE (2015) 10:e0143814. doi: 10.1371/journal.pone.0143814

127. Lennox R, Porter DW, Flatt PR, Holscher C, Irwin N, Gault VA. Comparison of the independent and combined effects of sub-chronic therapy with metformin and a stable GLP-1 receptor agonist on cognitive function, hippocampal synaptic plasticity and metabolic control in high-fat fed mice. Neuropharmacology (2014) 86:22-30. doi: 10.1016/j.neuropharm.2014.06.026

128. Bertoldo MJ, Guibert E, Tartarin P, Guillory V, Froment P. Effect of metformin on the fertilizing ability of mouse spermatozoa. Cryobiology (2014) 68:262-8. doi: 10.1016/j.cryobiol.2014. 02.006

129. Adaramoye O, Akanni O, Adesanoye O, Labo O. Evaluation of toxic effects of metformin hydrochloride and glibenclamide on some organs of male rats. Niger J Physiol Sci. (2012) 27:137-44.

Conflict of Interest Statement: The authors declare that the research was conducted in the absence of any commercial or financial relationships that could be construed as a potential conflict of interest.

Copyright (๑ 2018 Faure, Bertoldo, Khoueiry, Bongrani, Brion, Giulivi, Dupont and Froment. This is an open-access article distributed under the terms of the Creative Commons Attribution License (CC BY). The use, distribution or reproduction in other forums is permitted, provided the original author(s) and the copyright owner(s) are credited and that the original publication in this journal is cited, in accordance with accepted academic practice. No use, distribution or reproduction is permitted which does not comply with these terms. 